\title{
SCIENTIFIC IDENTITY AND INQUIRY-BASED TEACHING AMONGST SECONDARY SCHOOL ADOLESCENTS
}

\author{
${ }^{1}$ Nik Azmah Nik Yusuff, ${ }^{2}$ Norazilawati Abdullah, ${ }^{3}$ Noraini Mohamed Noh \\ ${ }^{1.2 .3}$ Universiti Pendidikan Sultan Idris, Malaysia \\ 35900 Tanjong Malim, Perak
}

Received : 10 Oktober 2017; Accepted : 10 November 2017; Published : 15 December 2017

\begin{abstract}
Like other countries, Malaysia is concern about the students' engagement with science in upper secondary schools and the numbers pursuing the further study of science as their careers, thus this research was carried out to demonstrate relationships between the five constructs: pupils' interest and attitude, inquiry learning, science activities outside school hours, aspirations to engage in science careers, and representation of science and scientists. Using a correlational research design, a set of Science Interest Instrument by Dillon et al., (2008) was adapted and translated to Malay Language and administered to a total of 938, 13-year-old and 14-year-old school students. The data collected were analyzed descriptively in terms of percentage, and inferentially using Pearson Correlation. The results indicated that there was a large positive correlation between interest and attitude towards science and inquiry learning. Also a strong relationship between high interest and attitude towards science, and aspiration of students to become scientists or taking up science jobs. The young students also had favourable representation of science and scientist. The result of this study was discussed in relations to students' science identity, and the government and parents could nurture this aspect of identity in adolescents.
\end{abstract}

Keywords Science Identity, Inquiry Learning, Aspirations In Science Careers.

\begin{abstract}
Abstrak
Sebagaimana negara lain, Malaysia risau tentang penglibatan pelajar dalam sains sekolah menengah tinggi dan bilangan yang melanjutkan pelajaran dalam bidang sains sebagai kareer, makanya kajian ini dilaksanakan untuk melihat perhubungan di antara lima konstruk: minat dan sikap, pembelajaran inkuiri, aktiviti sains di luar waktu sekolah, aspirasi untuk terlibat dalam kareer sains, dan perwakilan sains dan saintis. Menggunakan rekabentuk korelasional, satu set Instrumen Minat Sains oleh Dillon et al.,(2008) yang diubahsuai dan diterjemahkan kepada Bahasa Melayu, ditadbirkan kepada sejumlah 938 pelajar sekolah berumur 13 dan 14 tahun. Data yang dikumpul dianalisis secara deskriptif dalam bentuk peratusan dan secara inferensial menggunakan Korelasi Pearson. Keputusan menunjukkan bahawa terdapat korelasi yang tinggi dan positif di antara minat dan sikap terhadap sains dengan pembelajaran inkuiri. Juga perhubungan yang tinggi antara minat
\end{abstract}


dan sikap yang tinggi terhadap sains dengan aspirasi pelajar untuk menjadi saintis atau bekerja dalam bidang sains. Pelajar juga mempunyai tanggapan yang positif mengenai perwakilan sains dan saintis. Keputusan kajian ini telah dibincangkan secara hubungannya dengan identiti sains pelajar, serta kerajaan dan ibu bapa boleh memupuk aspek identiti ini dalam diri remaja.

Kata kunci Identiti Saintifik, Pembelajaran Inkuiri, Aspirasi Dalam Kareer Sains.

\section{INTRODUCTION}

The concern about students' engagement with school science and the number pursuing the further study of science is an international phenomenon and a matter of considerable concern among policy makers. In countries practising central education systems, a central policy goal has been to strengthen educational provision with a view to raising levels of attainment and participation, and to increasing the proportion of students following science-based options in upper-secondary and higher education to achieve a ratio of 60:40 for science-versus arts-based students (Eng Tek Ong \& Ruthven K., 2010). This is an effort by the government to increase the number of science-literate students in the country without meaning to undermine the arts-based subjects. However the effort still seems futile because over recent years, reports by the Malaysia Ministry of Education indicate levels of attainment and participation of students in science-based options has dwindled from already low starting percentage especially in the early 2000s where students are given the choice to opt for preferred streams when entering upper secondary schools unlike before. Based on students' enrolment in upper secondary schools in Malaysia, including Day-Schools and Boarding Schools (Residential, Religious, Technical/Vocational), the ratio of science to arts was $37.8: 62.2$ (Nik Azmah, 2007). Research on the 2020 Human Capital Road Map reported the ratio of $27: 73$ in 2012, ( UTM, 2012) and declined to the current ratio of 20 : 80 (Dzulkifli, 2013), but increased to $42: 58$ in 2014 (Najib , 2014). Although in many Western industrialized countries, science is unpopular with students and enrolment is considered too low, and too few students choose science (Organization for Economic Cooperation and Development [OECD], 2006; Roth, 2003). It is of greater concern to countries like Malaysia because they have yet to achieve the developed status.

Many past research reported that students thought that science subjects were tough and very abstract (Sjøberg, 2002, cited in Schreiner, 2006). Many were not interested in science or mathematics (Mohd Hasani, 2007; Bou Jaoude, 1992; Niaz \& Robinson, 1993; Aminah, 2011). Students have negative perception towards science subjects since primary school level. Students thought that science subjects are tough and they cannot excel in the science subjects, this will affect their chances to enter universities. The exam-oriented school system causes students to choose arts stream rather than science in the hope to get excellent exam results as means to university entrance. However more science-fields are offered at university levels than arts, but less takers, and ultimately the country lose out the much needed science and technology human capital. 
Various factors are believed to affect students' choice of whether to follow science-based options upon entering upper secondary schools. However recent studies have advocated identity formation of students may influence their choices. The term identity may be defined as the distinctive character belonging to any given individual, or shared by all members of a particular social category or group. It comes from the French word identité which finds its linguistic roots in the Latin noun identitas, -tatis, itself a derivation of the Latin adjective idem meaning "the same". The term is thus essentially comparative in nature, as it emphasizes the sharing of a degree of sameness or oneness with others in a particular area or on a given point. "Identity" may be distinguished from "identification", the former is the label whereas the latter refers to the classifying act itself. Identity is thus best construed as being both relational and contextual, while the act of identification is best viewed as inherently processional (Rummens, 1993).

From psychological perspective, identity relates to self-image (a person's mental model of himself), self-esteem, and individuality. In cognitive psychology, the term "identity" refers to the capacity for self-reflection and the awareness of self (Leary \& Tangney, 2003). Abdelal, Herrera, Johnston, and McDermont (2006) state that the use of the concept of identity in social science is growing, but that a wide variety of definitions are used. In this study, identity is focused as "role-identity in a socio-psychological sense". After Burke (1980), Taconis et al. defines it as: "a particular and coherent set of personal characteristics of an individual perceived as shared with a particular category of persons and distinguishing the individual from other persons". Similarly, Carlone and Johnson (2007) describe a person with a science identity as a person that "recognizes him/herself and gets recognized by others as a "science person". This dual nature of recognizing oneself while simultaneously being recognized in a corresponding fashion is at the heart of the concept of identity. For science, this could concern characteristics like: talking in a scientific manner (Lemke, 1990), being less socially oriented (Hannover \& Kessels, 2004), showing particular skilled ways of performing scientific activities (Ford \& Wargo, 2007), and holding values and epistemological beliefs that are associated with science (Duschl, 2008).

Research has demonstrated that the majority of young children have positive attitudes to science at age ten but that this interest then declines sharply and by age fourteen, their attitude and interest in the study of science has been largely formed (Archer et al., 2010). Further recent evidence that children's life-world experiences prior to 14 are the major determinant of any decision to pursue the study of science comes from a survey by the Office for Public Management for the Royal Society (2006) of 1,141 science, engineering, and technology practitioners' reasons for pursuing scientific careers. In the year 2013, Malaysia has almost 2.7 million adolescents of ages between 10 and 14 years (Malaysia Department of Statistics, 2013). This is about $10 \%$ of the total population. During this stage of their lives, the process of identity formation is taking place. High or low appreciation of science education has been related to the specific nature of the process of this identity formation. Thus, we would contend that effort could be productively expended by (a) understanding what are the formative influences 
on student career aspirations between the ages of 11 and 12 and (b) attempting to foster and maximize the interest of this cohort of young people in careers related to science, technology, engineering, and mathematics.

The adolescents' science identity are measured using the questionnaires. Whereby the first, third, fourth and fifth constructs within the questionnaires contain questions that reflect their science identity. The second construct contain questions on inquirí learning that they have experienced.

Therefore to understand these young people more, the objective of this research is to find relationships between the five constructs: pupils' interest and attitude, inquiry learning, science activities, aspirations, and representation of science and scientists. Specifically the objectives are: (a) to examine pupils' interest and attitude in relations to inquiry learning, science activities, aspirations, and representation of science and scientists, (b) to examine pupils' aspirations to engage in science careers in relations to science activities, inquiry learning, and representation of science and scientists, (c) to examine pupils' inquiry learning in relations to science activities, and representation of science and scientists, and (d) to examine pupils' science activities in relations to representation of science and scientists.

\section{METHODOLOGY}

This research is about finding relationships, therefore the appropriate research design for this study is correlational design (Creswell, 2008; Gay, Mills, \& Airasian, 2009). A set of Science Interests Instrument of Dillon et al.(2008) was adapted and used. It was a questionnaire with closed and open questions. The booklet contained 67 substantial questions on science interest and attitude towards science learning, inquiry learning, representation of science and scientists, aspirations to engage in science careers, and doing science activities when not in school. Twenty-nine items asked were about the pupils' science interest and attitude towards science learning, ten items were about inquiry learning, nine items were about how they identify science and scientists, twelve items were about the pupil's aspirations to engage in science careers, and seven items were about doing science activities when they were not in schools. The duration of time needed to complete the questionnaire was about 30 minutes. Further more, the adapted version was translated to Bahasa Malaysia and was piloted to ascertain its reliability. Overall reliability index of Cronbach Alpha of the instrumen was 0.776. Reliability index of Cronbach Alpha for each construct was between 0.704 to 0.852 (Science activities when not in school, .714; Aspirations to engage in science careers, .851; Interests and attitude towards science, .716; Inquiry learning, .857; Representation of science and scientists, .770)

Research population was form 1 and form 2 (13 to 14 years old) mainstream secondary school pupils in the state of Kelantan, Perak and Selangor. Nine hundred and thirty eight pupils were selected randomly and became the samples for this research. The adapted and translated Science Interest Instrument was sent by-hand to all selected schools after getting permission from The Ministry of Education of Malaysia and the 
school principals. Science teachers of the secondary schools involved distributed the questionnaires among their school pupils. Within 5 months after the instrument was sent to the schools, the questionnaires were returned by various ways including collection by-hands and postage. The information from the data were then analysed descriptively, and inferentially using Pearson Correlation analysis.

\section{RESULTS}

\section{a. Pupils' Interest and Attitude in Relations to Inquiry Learning, Science Activities, Aspirations, and Representation of Science and Scientists}

The relationship between interest and attitude towards science and inquiry learning was investigated using Pearson product-moment correlation coefficient (Table 1). According to Cohen (1988) who suggested $r=.50$ to 1.0 as large, thus there was a large positive correlation between the two variables $[\mathrm{r}=.513, \mathrm{n}=938, \mathrm{p}<.0005]$, with high interest and attitude towards science was associated with high inquiry learning. Table 2 also showed the relationship between interest and attitude towards science and doing science activities when not in school. According to Cohen (1988) who suggested $r$ $=.30$ to .49 as medium, thus there was a medium positive correlation between the two variables $[\mathrm{r}=.380, \mathrm{n}=938, \mathrm{p}<.0005]$, with high interest and attitude towards science was associated with higher doing science activities when not in school. It also showed the relationship between interest and attitude towards science and aspiration to engage in science careers, whereby there was a large positive correlation between the two variables $[\mathrm{r}=.545, \mathrm{n}=938, \mathrm{p}<.0005]$, with high interest and attitude towards science was associated with higher aspiration to engage in science careers. It also showed the relationship between interest and attitude towards science and representation of science and scientists as well, whereby there was a medium positive correlation between the two variables $[\mathrm{r}=.442, \mathrm{n}=938, \mathrm{p}<.0005]$, with high interest and attitude towards science was associated with higher representation of science and scientists. 
Table 1 Correlation between interest in and attitude towards science, and inquiry learning, science activities, aspirations, and representation of science and scientists

Inquiry learning

Pearson Correlation

Sig. (2-tailed)

$\mathrm{N}$

$.513^{* *}$

.000

938

Doing science activities when not in school

Sig. (2-tailed) .000

$\mathrm{N}$

Interest in

and attitude

towards

science

Sig. (2-tailed)

.545

$\mathrm{N}$

.000

938

Representation of science and scientists

$.442^{* *}$

Sig. (2-tailed)

.000

$\mathrm{N}$

938

**Correlation is significant at the 0.01 level (2-tailed)

\section{b. Pupils' Aspirations to Engage in Science Careers in Relations to Science Activities, Inquiry Learning, and Representation of Science and Scientists}

Table 2 showed the relationship between aspirations to engage in science careers and doing science activities when not in school as investigated using Pearson productmoment correlation coefficient. According to Cohen (1988) who suggested $\mathrm{r}=$ .30 to .49 as medium, thus there was a medium positive correlation between the two variables [ $\mathrm{r}=.449, \mathrm{n}=938, \mathrm{p}<.0005]$, with high aspirations to engage in science careers was associated with higher doing science activities when not in school. Table 3 also showed the relationship between aspirations to engage in science careers and inquiry learning and it was found there was a medium positive correlation between the two variables $[\mathrm{r}=.461, \mathrm{n}=938, \mathrm{p}<.0005]$, with high aspirations to engage in science careers was associated with higher inquiry learning. It also showed the relationship between aspirations to engage in science careers and representation of science and scientists, whereby there was a medium positive correlation between the two variables $[r=.416$, $\mathrm{n}=938, \mathrm{p}<.0005]$, with high aspirations to engage in science careers was associated with higher representation of science and scientists. 
Table 2 Correlation between aspirations to engage in science careers, and doing science activities when not in school, inquiry learning, and representation of science and scientists.

Doing science activities when not in school

Pearson Correlation

$.449^{* *}$

Sig. (2-tailed) $\quad .000$

$\mathrm{N}$

938

Inquiry learning

$\begin{array}{cc} & .461^{* *} \\ \text { Sig. (2-tailed) } & .000 \\ \text { N } & 938\end{array}$

Representation of science and scientists

Aspirations to

engage in science careers

Sig. (2-tailed)

$.416^{* *}$

$\mathrm{N}$

.000

938

**Correlation is significant at the 0.01 level (2-tailed)

\section{c. Pupils' Inquiry Learning in Relations to Science Activities, and Representation of Science and Scientists}

Table 3 showed the relationship between inquiry learning and doing science activities when not in school as investigated using Pearson product-moment correlation coefficient. According to Cohen (1988) who suggested $r=.30$ to .49 as medium, thus there was a medium positive correlation between the two variables $[\mathrm{r}=.414$, $\mathrm{n}=938, \mathrm{p}<.0005$ ], with high inquiry learning was associated with higher doing science activities when not in school. Table 3 also showed the relationship between inquiry learning and representation of science and scientists and it showed that there was a medium positive correlation between the two variables [ $\mathrm{r}=.336, \mathrm{n}=938, \mathrm{p}<.0005]$, with high inquiry learning was associated with higher representation of science and scientists. 
Table 3 Correlation between inquiry learning and doing science activities when not in school.

Doing science activities when not in school

$\begin{array}{cccc}\text { Inquiry learning } & \text { Pearson Correlation } & 1 & .414^{* *} \\ & \text { Sig. (2-tailed) } & & .000 \\ \text { N } & 938 & 938 \\ & & \text { Representation of science and scientists }\end{array}$

Pearson Correlation $\quad .336^{* *}$

Sig. (2-tailed) $\quad .000$

$\mathrm{N} \quad 938$

**Correlation is significant at the 0.01 level (2-tailed)

\section{d. Pupils' Science Activities in Relations to Representation of Science and Scientists}

Table 4 showed the relationship between doing science activities when not in school and representation of science and scientists as investigated using Pearson productmoment correlation coefficient. According to Cohen (1988) who suggested $r=.30$ to .49 as medium, thus there was a medium positive correlation between the two variables $[\mathrm{r}=.301, \mathrm{n}=938, \mathrm{p}<.0005]$, with high doing science activities when not in school was associated with higher representation of science and scientists.

Table 4 Correlation between doing science activities when not in school, and representation of science and scientists.

\begin{tabular}{lcr}
\hline & & \multicolumn{2}{c}{$\begin{array}{c}\text { Representation of science } \\
\text { and scientists }\end{array}$} \\
Doing science & Pearson Correlation & $.301^{* *}$ \\
activities when & Sig. (2-tailed) & .000 \\
not in school & $\mathrm{N}$ & 938 \\
\hline
\end{tabular}

**Correlation is significant at the 0.01 level (2-tailed)

\section{DISCUSSION}

The attitudes towards science is found to increase for all students across gender, race, pupils with special education needs, and socioeconomic status when inquiry practices are used (Kanter \& Konstantopoulos, 2010; Scruggs et al., 1993; Wilson et al., 2010). All of these researchers have found inquiry methods to benefit pupils and incorporate researched-based teaching techniques such as: building on prior knowledge, increasing metacognition, a high emphasis on understanding, and social learning (Berg,Bergnedal, Lundberg, \& Tibell, 2003; Hofstein \&Lunetta, 2004; Wilson et al., 2010). The result of this research is found to complement those findings as on examining pupils' interest 
and attitude in relations to inquiry learning, we find a large positive correlation between the two variables. In order to solve everyday problems, children consciously or unconsciously engage in scientific thinking and analysis of situations. This scientific approach to solving everyday problems needs to be encouraged and developed in a formal educational setting where teachers continuously change and organize curriculum and instruction to meet the needs of the children (Poon, Tan \& Tan, 2009). However, as Wallace and Kang (2004) state that science teachers must possess abilities that include a deep understanding of scientific inquiry, strong inquiry-based instructional practice, and the ability to guide and organize pupils to conduct inquiry activities. According to Chung-Hsien Tseng et al. (2012), experienced science teachers hold multiple perspectives on inquiry and inquiry teaching. To overcome obstacles they encountered when implementing inquiry teaching, they develop useful skills or strategies to enhance students' inquiry activities from their authentic experience. An example of one category of the strategies developed is, "for classroom practice," the three codes are "Follow well-structured steps," "Develop students' inquiry skills," and "motivate." Some teachers emphasize that some students have to be developed for their inquiry skills. Teachers have to guide students how to explore, collect data, discuss, form conclusions, and present inquiry outcomes. Besides that teachers should develop cognitive conflict strategies to motivate students. These skills if acquired by science teachers will be beneficial to complement their content knowledge that would lead to better teaching skills and improve young people's interest to study science.

There is a medium positive correlation between doing science activities when not in school and inquiry learning as well. These findings are paralleled to research done by Ahmad Nurulazam et al., (2010) on "low performing" 14 and 16year old secondary school students, whereby they found that the students' positive attitude in certain aspect of learning science in school, practical work in science and the importance of science provide good conditions to develop their interests in learning science. However, according to them, the pupils' overall attitudes need to be improved. And efforts should be given in order to make them appreciate more on science outside of school in their learning. In order for this to happen, they suggest science teachers need, for example, to integrate more science activities outside of school. High interest and attitude towards science is associated with higher doing science activities when not in school which is a form of informal education as we have found in this research and concur the view of science education encompasses a significant part of a child's formal and informal education. Our research also shows a medium positive correlation between doing science activities when not in school and, interests and attitude towards school science. When their interest and attitude towards science are high it shows through their behaviour whereby they carry out more science activities outside school hours.

Concurrently the young people's aspirations to engage in science careers or become scientists or taking up science jobs are found to be of large positive correlated to interest in and attitude towards science. If in schools, the pupils can experience challenging and relevant science learning and teachers can engage them, it is likely that the pupils' interests and attitude toward science become positive. Accordingly, activity -based and issue oriented science instruction enhance positive attitudes 
towards science (Siegel \& Ranney, 2003), and Trumper (2006) found that the quality of teaching of school science is a significant determinant of attitude towards school science. To maintain the high interest and attitude towards science would mean to maintain the young adolescents' aspiration to study science in the future. As we find that aspirations to engage in science careers and inquiry learning is at a medium positive correlated therefore it supports the statement about activity-based and issue oriented science instruction above.

This study also shows a medium positive correlation between interest and attitude and representation of science and scientists. Representation of science and scientists includes attributes such as being respected by people, intelligent, having exciting jobs, and can make a difference in the world. There is a medium positive correlation between aspirations to engage in science careers and representation of science and scientists. Also a medium positive correlation between inquiry learning and representation of science and scientists. Again a medium positive correlation between young people's doing science activities when not in school and representation of science and scientists. Therefore the results of this study indicate favourable representation of science and scientists amongst young people who show interest in and good attitude towards science. Therefore this study supported what has been found by Kessels and Taconis (2011) in their study that young people consider the typical science teacher to be intelligent and motivated.

However the research findings seem to contradict with the statement by Kessels and Taconis (2011), which state the typical hard sciences teachers are perceived as being less similar to young people's own self image; in a more negative way and more distant from the image the young people have of themselves. The typical teacher of hard sciences are perceived as being less attractive, less socially competent and integrated, less creative and emotional, and as more arrogant and self-centred than the typical teacher of languages.

Likewise, as Osborne and Dillon (2008) wrote that the issue of why school science is not as engaging for young people as other subjects is complex. Nevertheless, two factors would seem important. Students now live in a culture which is increasingly reflexive and one, in addition, in which they are confronted with a much wider range of subject choice than was the case in the past. Adolescence is a period of identity formation and there is good evidence that a critical issue for young people is how their subject choice frames their sense of self-identity - in particular, how it reflects their personal values. School science has done little to consider how it might appeal to the values and ideals of contemporary youth and their culture. Hence, their view is that what school science requires is a new vision of why an education in science matters that is widely shared by teachers, schools and society. In particular, it needs to offer a better idea of what kinds of careers science affords - both in science and from science - and why these careers are valuable, worthwhile and rewarding.

Findings from this research by the constructs developed have indicated a link to the young people' scientific identities and their future career choice. The young people are found to have associated science and scientists in a favourable image, however this could change as they grow older. A growing body of recent research has shown that most students develop their interest in and attitudes towards school science before the 
age of 14. Knowledge about the interest in and attitude of young adolescents towards science education could benefit the countries concern in drawing up accurate education policies, and science teachers in their teaching and learning strategies. Any changes in their science identity should quickly be detected and therefore efforts toward closing the gap of dissimilarity between science and young people's self image would be necessary.

\section{CONCLUSION}

In summary, inquiry-based science teaching which includes helping pupils explore scientific phenomena is seen as predominant in making science classes interesting and exciting. Even though "doing" science seems interesting, the notion of learning of interesting things in science lesson does not directly influence students' interest in science triggers further research to uncover the reasons behind it. Our finding in this study on 13-year old and 14-year old secondary school pupils however, do not augur completely well with the notion. They are found (most did) to be full of interest in science and their attitude toward science are favourable. Results of this study also indicate a strong relationship between high interest in and attitude towards science, and aspiration of young people to become scientists or choosing science-related profession. However as the young people grow older their interests and attitudes might change according to the notion. Thus efforts to be done by science teachers are clear - they must be competent to manage their science class using inquiry-based methods to sustain pupils' interest in science and having favourable attitude toward science. As well as supporting the young students in developing their science identities.

\section{REFERENCES}

Abdelal,R., Herrera,Y. M., Johnston, A. I., \& McDermott, R. (2006). Identity as a variable. Perspectives on Politics, 4, 695-711.

Ahmad Nurulazam , M.Z., Mohd Ali, S., Rohandi, \& Azman, J. (2010). Using the Rasch Model to measure students" attitudes toward science in "low performing" secondary schools in Malaysia. International Education Studies, 3(2), 56-63.

Aminah Ayob (2011). Analisis status pendidikan sains dan matematik, dan persediaan tenaga manusia sains dan teknologi Negara. Jurnal Pendidikan Sains \& Matematik Malaysia, 1(1), 82-97.

Berg, C. A., Bergendahl, V. C., Lundberg, B., \& Tibell, L. (2003). Benefiting from an open-ended experiment? A comparison of attitudes to, and outcomes of, an expository versus an open-inquiry version of the same experiment. International Journal of Science Education, 25(3), 351-372.

Bou Jaoude, S. B. (1992). The relationship between students' learning strategies and change in their misunderstandings during a high school chemistry course. Journal of Research in Science Teaching, 29(7), 157-172

Burke, P. J. (1980). The self: Measurement requirements from an intergrationist perspective. Social Psychology Quarterly,43, 18-29 
Carlone, H. B. \& Johnson, A. (2007). Understanding the science experiences of successful women of colour: Science identity as an analytic lens. Journal of Research in Science Teaching, 44,1187-1218.

Chung-Hsien Tseng, Hsiao-Lin Tuan, \& Chi-Chin Chin. (2012). How to help teachers develop inquiry teaching: Perspectives from experienced science teachers. Res Sci Educ. Published online 06 May 2012. Springer.

Cohen, J. (1988). Statistical power analysis for the behavioral sciences. Hillsdale, NJ: Erlbaum.

Creswell, J. W. (2008). Educational research: Planning, conducting, and evaluating quantitative and qualitative research ( $3^{\text {rd }}$.ed.) NJ: Pearson Education International.

Duschl, R. (2008). Science education in three-part harmony. Balancing conceptual, epistemic and social learning goals. Review of Research in Education, 32,268291.

Dzulkifli Abdul Razak (2013). Humanising science. 2020 Human Capital Road map identified reasons for a decline in interest among students. Retrieved from NSTP IMAGE ARCHIVE. Digital Collection DC5: Text Archive. Detail view. Mozila firefox.

Eng Tek Ong \& Ruthven K, (2010). The distinctiveness and effectiveness of science teaching in tha Malaysian 'Smart school'. Research in Science and Technological Education,. 28(1), 25-41.

Ford, M.J. \& Wargo, B.M. (2007). Routines, roles, and responsibilities for aligning scientific and classroom practices. Science Education, 91,133-157.

Gay, L. R., Mills, G. E., \& Airasian, P. (2009). Educational research (9 ${ }^{\text {th }}$. ed.). New Jersey: Merrill.

Hofstein, A., \& Lunetta, V. N. (2004). The laboratory in science education: Foundations for the twenty-first century. Science education, 88(1), 28-54.

Kanter, D. E., \& Konstantopoulos, S. (2010). The impact of a project-based science curriculum on minority student achievement, attitudes, and careers: The effects of teacher content and pedagogical content knowledge and inquiry-based practices. ScienceEducation.

Kessels, U. \& Taconis, R. (2011). Alien or alike? How the perceived similarity between the typical science teacher and a student's self-image correlates with choosing science at school. Res Sci Educ. Published online: 27 May 2011. Springer.

Leary, M.R. \& Tangney, J. P. (2003) Handbook of self and identity (http://books.google. com/?id=fa4 5xN9c5wC). New York: Guilford Press. ISBN 1572307986. http:// books.google.com/?id=fa4 5xN9c5wC.

Osborne, J. \& Dillon, J. (2008). Science Education in Europe: Critical Reflections. www.pollen-europa.net/pollen_dev/Images_Editor/nuffieldreport.pdf. Retrieved 2011-12-30.

Lemke, J. (1990). Talking science: Language, learning, and values. Norwood, NJ: Ablex.

Malaysia Department of Statistics. (2013). Population by age group and sex. Retrieved 12 July, 2013, from http://www.kpwkm.gov.my/BM/ Upload/20080624_034725_12064_j1.4.pdf. 
Mohd Hasani Dali (2007). A case study of peer group pressure within and outside school. Jurnal Penyelidikan Pendidikan. 09,16-37.

Najib Razak. (2014). www.nst.com.my/node/36346.

Niaz, M. \& Robinson, W.R. (1993). Teaching algorithmic problem solving or conceptual understanding; Role of development level, mental capacity and cognitive style. Journal of Science and Educational Technology, 2(2), 407-416.

Nik Azmah Nik Yusuff (2007). Kualiti perkhidmatan pengurusan pendidikan sains dan matematik dalam wawasan pendidikan negara. Universiti Kebangsaan Malaysia. Doctor of Philosophy thesis.

Organization for economic Cooperation and Development. (2006). Evolution of student interest in science and technology studies policy report. Retrieved from http://www.nieuwescheikunde.nl/.

Poon, C., Tan, D., \& Tan, A. (2009). Classroom management and inquiry-based learning: Finding the balance. Science Scope, 32 (9), 18-21. (EJ850038).

Roth, W.-M. (2003). Learning science in/for the community. Paper presented at Congresso Enseńannza de las Ciencias, Barcelona, Spain.

Rummens, J. (1993). Personal Identity and Social Structure in Sint Maartin/ SaintMartin: a Plural Identities Approach. Unpublished Thesis/Dissertation: York University.

Schreiner, C. (2006). Exploring a ROSE-garden: Norwegian youth's orientations towards science - seen as signs of late modern identities (Unpublished doctoral dissertation). Department of Teacher Education and School Development, University of Oslo, Oslo, Norway.

Scruggs, T. E., Mastropieri, M. A., Bakken, J. P., \& Brigham, F. J. (1993). Reading versus doing: The relative effects of textbook-based and inquiry-oriented approaches toscience learning in special education classrooms. The Journal of Special Education,27(1), 1.

Siegel, M. A., \& Rannery, M. A. (2003). Developing the changes in attitude about the relevance of science (CARS) questionnaire and assessing two high school science classes. Journal of Research in Science Teaching, 40(8), 757-775.

Taconis, R., Lesley G. M. de P-S, Hendry, S., Perry J. den Brok, \& Beijaard, D. (2010). The construction of a questionnaire to evaluate the science orientedness of students' identities as learners from a cognitive perspective. Educational Research and Evaluation, 16(4),383-400.

UTM. Penolong Pendaftar Pejabat Hal Ehwal Korporat, Universiti Teknologi Malaysia. Retrieved 5 September 2013 from www.moe.gov.my/bpk/v2/?optien=com conte

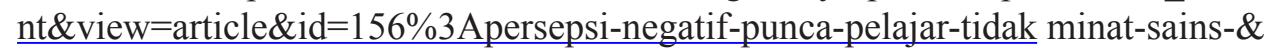

Wallace, C. S., \& Kang, N. H. (2004). An investigation of experienced secondary science.

teachers' beliefs about inquiry: An examination of competing belief sets. Journal of research in science teaching, 41(9), 936-960.

Wilson, C. D., Taylor, J. A., Kowalski, S. M., \& Carlson, J. (2010). The relative effects and equity of inquiry-based and commonplace science teaching on students' knowledge, reasoning, and argumentation. Journal of Research in Science Teaching, 47(3), 276-301. 